\section{De ética y estética, un abordaje del lenguaje inclusivo}

Juan Manuel Chávez

Escritor. Autor de libros de narrativa y ensayo, géneros en los cuales ha sido galardonado tanto en su país natal, Perú como en el extranjero.

Investigador (Unidad de Estudios Biográficos de la Universidad de Barcelona, España).

RECEPCIÓN: 01/04/20

ACEPTACIÓN FINAL: 04/06/20

\section{Resumen}

El presente artículo plantea el lenguaje inclusivo como un horizonte múltiple y flexible, a partir del cual se abordan las representaciones de lo foráneo, la discapacidad y el sexismo. Bajo esta premisa, se vale de una serie de ejemplos discursivos y dos manifestaciones literarias para arribar a una perspectiva en que la comunicación gana en claridad, pertinencia, justicia y empatía.

Palabras clave: lengua; migración; discapacidad; sexismo; lenguaje inclusivo

Sujetos y relaciones en extensión universitaria / Perspectivas

\title{
다(1)(5)
}

Doctorando en Lenguas, Literaturas, Culturas y sus Aplicaciones (Universidad de Valencia, España).

juanmanuelchavez@gmail.com

(iD) orcid.org/0000-0001-9797-6090
Of ethics and aesthetics, an approach to inclusive language

\section{Abstract}

This article addresses inclusive language as a multiple and flexible horizon, from which representations of the foreign, disability and sexism are addressed. Under this premise, this article uses a series of discursive examples and two literary manifestations to arrive at a perspective in which communication gains clarity, relevance, justice and empathy.

Keywords: language; migration; disability sexism; inclusive language
De ética e estética, uma abordagem à linguagem inclusiva

\section{Resumo}

Este artigo aborda a linguagem inclusiva como um horizonte múltiplo e flexível, a partir do qual as representações do forâneo, da deficiência e do sexismo são abordadas. Sob essa premissa, este artigo utiliza uma série de exemplos discursivos e duas manifestações literárias para chegar a uma perspectiva em que a comunicação ganha clareza, pertinência, justiça e empatia.

Palavras-chave: idioma; migração; deficiência; sexismo; idioma inclusivo

Para citación de este artículo: Chávez, J. M. (2020). De ética y estética, un abordaje del lenguaje inclusivo. +E: Revista de Extensión Universitaria, 10(12.Ene-Jun), 1-5. doi: 10.14409/extension.2020.12.Ene-Jun.9324. 
El académico francés Charles Perrault tejió con recursos literarios y afán moralizante las tradiciones populares de su tiempo para la escritura de sus cuentos; fueron ocho y cada uno pasaba de las formas de la oralidad al refinamiento de la narración cortesana del siglo XVII en Europa. En otra lengua, en otra época y en otro continente, Gabriela Mistral tomó algunas de aquellas creaciones e hizo sus versiones en verso alejandrino. El más sugerente de los originales y de los suyos es Caperucita roja, pues triunfa el villano y el mal que representa.

De las tantas variantes que existen de Caperucita roja, luego de la historia fijada por Charles Perrault, la más popular es la que hicieron los hermanos Grimm en el siglo XIX. El lobo devora a la abuela y a su nieta, quien había formulado tres inocentes preguntas sobre el aspecto del animal disfrazado y recibió igual número de respuestas que son de horror; pero la historia no acaba con la muerte de ellas. Los hermanos Grimm buscan otro descenlace a la trama con introducir un nuevo personaje, del cual no tenían deslizada la menor referencia hasta entonces: el cazador, que abre al lobo y libera a las cautivas que estaban en su vientre, ni masticadas ni digeridas; a la casualidad de esta aparición providencial le suman un rebose de inverosimiltud. El cuento de los hermanos Grimm es, a fin de cuentas, tranquilizador, aunque paternalista: la fiera es vencida gracias al rescate que hace el hombre de las mujeres. Por supuesto, esta versión extendida no fue de interés para una escritora como Gabriela Mistral.

Con un total de 48 versos repartidos en 12 estrofas de cuatro versos alejandrinos cada uno, esa exactitud de 14 sílabas por línea, Gabriela Mistral es fiel a la esencia del original e incluso ahonda en la crítica que subyace a la historia. Caperucita es descrita físicamente como una muchacha de rizos rubios, mientras que sus cualidades son la ternura y el encanto. Por su parte el lobo, cuyos ojos son diábolicos, explota del modo más traicionero la conversación amistosa que Caperucita le brinda en el bosque. Ella le habló de la abuela, de su salud quebrada y que está yendo a verla, ante lo cual el lobo decide ganarle a Caperucita en llegar a su destino. La bestia, que doblega a la viejecita con su voracidad, ríe mientras se la come; a su vez, aguarda por la muchacha:

Caperucita ha entrado, olorosa de bayas.

Le tiemblan en la mano gajos de salvia en flor.

"Deja los pastelitos; ven a entibiarme el lecho".

Caperucita cede al reclamo de amor. (2016)

Algo inquieta a Caperucita en la casa, a donde llega por encargo de su mamá. La muchacha tendrá dudas, y por eso pregunta ante las orejas tan raras de la supuesta viejecita; sentirá miedo, y por eso inquiere sobre los ojos tan dilatados; estará aterrada, y por eso consulta en torno a los dientes tan grandes. ¿Qué clase de villano es el lobo y qué es lo que representa? Es vil, con una voracidad que también es carnal: abusa de la confianza de una menor, después la engaña y, finalmente, la insta sacando provecho de su candor.

Más allá de cualquier melindre y tabú temático, Gabriela Mistral hila en torno a la sordidez de la sexualidad: una niña que es víctima. Aquí no importa la ropa que llevaba, los rizos que lucía o el encanto que brindaba, pues su ruina es la bestia que planificó devorarla; "y ha exprimido como una cereza el corazón", dice en su último verso. Es tal el empeño del lobo por conseguir a la protagonista, que antes regocija su malicia acabando con la abuela. 
A la fecha hay un rescate de Gabriela Mistral, o mejor dicho una reivindicación. Fuera de las ediciones conmemorativas como Gabriela Mistral en verso y prosa. Antología de 2019, preparada y avalada por Real Academia Española y la Asociación de Academias de la Lengua Española, está la popularización de su figura y de su obra por una nueva generación que valora lo que desdeñaron las previas: muros en las calles de Santiago de Chile con sus versos y su nombre coreado en las luchas feministas de América Latina.

La Gabriela, reconocida con el Premio Nobel unos meses después de terminada la Segunda Guerra Mundial en 1945, es la primera y única mujer en lengua española que ha recibido el galardón. Una condición pionera que es trasversal a su literatura y a su personalidad, atributo que su cuento Caperucita roja, publicado originalmente en su libro Ternura de 1924, anticipa rotundamente.

Dos lecciones básicas se extraen de la literatura, tal como ejemplifica el caso de Gabriela Mistral: podemos tener más de una versión de la realidad y, en consecuencia, novedosas interpretaciones. Esto conlleva un cambio de paradigmas. La inclinación hacia el lenguaje inclusivo es un cambio de paradigmas, pues valiéndonos del mismo idioma conseguimos dar una versión extra de la realidad y arribar a interpretaciones distintas en los actos comunicativos.

Quince años atrás, el diario El País advertía que un ciudadano medio español no utiliza más allá de 1000 palabras y solo los muy cultos alcanzan los 5000 vocablos, una media que incluso puede empeorar (¿no era el entrenador de la selección de fútbol de Inglaterra el que decía, hace una década, que le bastaban cien palabras para manejar a su plantel de estrellas?). El vocabulario de la lengua española se aproxima a las 300.000 palabras, de las cuales una mayoría emplea el 0,3\%; en suma, es un idioma que tenemos sin estrenar.

El primer sinceramiento en torno a la comunicación verbal atañe a las competencias: ¿conocemos las palabras? Lo cierto es que, por lo general, ignoramos casi todo lo que haría falta para expresar con el mínimo detalle y la máxima precisión cuanto sentimos, cuanto deseamos, cuanto lamentamos, cuanto sufrimos. En vez de adentranos en un bosque lexical, lo que hacemos es rotar una maceta con su austero yerbajo. Las relaciones interpersonales que establecemos de manera escrita y oral están limitadas por el estrecho perímetro de nuestras posiblidades lingüísticas. En tal sentido, un cambio de paradigma hacia un lenguaje de mayor inclusividad no supone un giro copernicano que dinamita los cimientos del idioma o arrasa las convenciones que empleamos para tratamos día a día, simplemente amplía el cerco que restringe la comunicación; esta ganará en calidad. El enfoque inclusivo nunca será un retroceso, ni tampoco un simple avance; conlleva progresar, lo que en términos pedagógicos se considera desarrollo.

El horizonte de cambio es amplio, pues abarca la conceptualización del otro y la estigmatización del extranjero, cuestiones en torno a la discapacidad y un carácter justiciero para afrontar el sexismo. Sobre lo primero, desterrar las practicas que identifican lo nocivo con una nacionalidad: "bandas de peruanos roban en Once" podía leerse en la prensa argentina, "el virus chino es responsable de la pandemia" se repite entre los políticos más irresponsables. El señalamiento del foráneo para constreñirlo a la peligrosidad y la amenaza, una encarnación de los males; palabras que son brechas en una sociedad de acogida que cierra, cual frontera territorial, las oportunidades de integración. Sobre lo segundo, la necesidad de reformar las representaciones de quienes poseen habilidades diferentes: ¿en verdad los carteles icónicos de personas en sillas de ruedas siempre deben ser con gente en actitud 
pasiva, espalda recta y brazo en perpendicular, trazos que aluden a un cuerpo tieso que no es capaz de valerse de sus extremidades superiores para moverse a gusto? La discapacidad impone un desafío al lenguaje porque en muchos casos opera bajo una comunicación desprovista palabras (para escuchar, para leer...), por tanto es un universo todavía en creación, que de entrada exige disposición, empatía e inventiva.

Y puestos en el sexismo, cabe recordar que las usanzas del habla y del discurso escrito han tendido a referir los avatares de nuestra especie bajo el devenir del hombre. Que la acepción de "hombre" sea, por un lado, la de ser racional en general y sea, también, la de varón en particular es motivo suficiente para desconfiar de su uso como equivalente de humanidad; sin intención o con ella, solapa el ejercicio de la mujer como agente dinámico de la historia. Cuando Neil Armstrong bajó a la superficie lunar, expresó su famosísima línea: That's one small step for a man, one giant leap for mankind... ese pequeño paso para un hombre, que es él; sin embargo, pudiendo decir humanity eligió el sinónimo mankind, que remite a raza de hombres. Con decir casi lo mismo, lo habría expresado mejor, pues Armonstrong deseaba englobar a ellos y ellas en la tarea colectiva de alcanzar el satélite de nuestro planeta.

El lenguaje inclusivo supone un virar que, incluso siendo leve y sutil, se agiganta en los efectos. La matemática ilustra como, aunque sea de un grado la separación angular entre dos líneas desde el vértice de origen, esta minucia es suficiente para que nunca más se crucen y, lejos de aquel punto de partida, la brecha de alejamiento sea cada vez mayor. Así de significativa puede ser la consecuencia del cambio, labrada hasta con el mínimo esfuerzo.

Hay un sexismo lingüístico y un sexismo social, que no es exclusivo del español. El primero tiene una condición discursiva; por ejemplo, decir: "la ingeniera Zapata es el nuevo jefe y coordinador del área". Esto subordina y oculta a la mujer, pues bien se podía afirmar: "es la nueva jefa y coordinadora del área". El segundo atañe al contenido y está anclado en la mentalidad de las personas; por ejemplo, emplear frases coloquiales como "es el hombre de la casa" para hablar de un tutelaje sobre el resto o "déjalo, es cosa de hombres" para delimitar campos de acción donde ellas están excluidas a priori. El sexismo lingüístico se afronta con modos alternativos de expresar, mientras que el sexismo social tiene que erradicarse, extirpado por ser una visión del mundo anclada en un pasado de virilidades trasnochadas y anacrónicas. Entonces, el lenguaje inclusivo pretende modificar las prácticas lingüisticas y, además, las concepciones y las acciones de las personas; de lo idiomático a lo sociocultural.

Subyace, por lo menos, una doble estrategia para arribar hacia un lenguaje incluso que haga frente al sexismo: visibilizando los géneros o neutrilizando los géneros. Una u otra opción debe responder a las necesidades que se desprenden de la intención comunicativa: duplico para diferenciar o comprimo para consolidar. Si se ha promulgado una nueva ley que favorece a una minoria nacional ("legislación que vela por intereses de los índígenas", en un discurso no inclusivo), esta novedad se puede referir visibilizando: "La legislación vela por intereses de las y los indígenas", pues se considera impresincible llamar la atención en torno a ellas, no solo ellos, para afrontar antiguas prácticas de exclusión. La otra manera de expresarlo es la siguiente: "La legislación vela por los intereses de la comunidad indígena", que auna por igual a quienes conforman el colectivo.

Interpelado por el sentido común y una cuota de pragmatismo, el lenguaje inclusivo tendría que eludir malabarismos que lo tergiversan: "Las/los compañeras/os de la fábrica están convocadas/os a una junta general para ser informadas/os sobre las mejoras laborales para 
ellas/os", cuando es posible una formulación de mayor claridad, sencillez y hasta brevedad: "Se cita al personal de la fábrica para una junta general en que se informará sobre las mejoras en las condiciones laborales". Lo primero es una caricatura que, siendo rústica en su redacción, es intricada en la expresión oral. Al triple objetivo comunicativo de la claridad, la sencillez y la brevedad, el lenguaje inclusivo aporta un rasgo de justicia que, además, es selecto.

Siete son las operaciones básicas para arribar a un lenguaje inclusivo; algunas, más determinantes que otras: 1) el uso de la barra oblicua para indicar la existencia de un par de opciones (gran amigo/a); 2) el empleo de nombres colectivos (población o ciudadanía, en vez de poblador o ciudadano); 3) la aplicación del género gramatical (gerente y gerenta, jueza y juez); 4) el uso de sustantivos de un solo género (personaje o víctima), asimismo con doble género (la especialista y el especialista); 5) operar giros lingüísticos (quien esté de acuerdo, en vez de el que esté de acuerdo); 6) evitar los tratamientos que subordinan (el señor y la señora López, con ese aludir a una pareja de esposos bajo el apellido del marido); 7) cuestionarse la cosificación de las personas (ellos perdieron todo en la tormenta, cuando ese "todo" y ese "ellos" son insuficientes para dar cuenta del suceso) y desterrar los tratos peyorativos (bruja, loca, histérica o dramática son, a fin de cuentas, insultos).

En su poema "Tras la expulsión", el Premio Nobel de Literatura Czesław Miłosz utiliza el lenguaje con plena consciencia de su intención lírica e hila las palabras para generar imágenes que respondan a cabalidad con su pretención ético-estética:

No corras más. Silencio. Qué suave cae la lluvia

En los tejados de esta ciudad. Qué perfección tiene

Todo. Ahora, para nosotros dos que nos despertamos

En un lecho real bajo la ventana de la buhardilla.

Para los hombres y las mujeres. O para esta planta

Dividida entre feminidad y masculinidad que se añoran.

Sí, este es mi regalo. Sobre las cenizas. (1984)

En esta historia de la humanidad, circunscrita al despojo, como es el poema de Miłosz, se enfatiza que la experiencia traumática de la expulsión no es exclusiva de ellos. Hay una visibilización de ellas que ni siquiera está reñida con el virtuosismo literario; por el contrario, es capaz de renovar meditaciones sobre la historia y la pérdida. El lenguaje inclusivo añade versiones e interpretaciones capaces de enriquecer la comunicación porque estas multiplican la visión del mundo, tal como hacen los versos de una y otro Nobel. A su vez, el lenguaje incluso es una propuesta para actualizar la cualidad ético-estética del idioma; en vez de la unicidad gramaticial que soslaya matices como una aplanadora, la seguidilla del cambio hacia la solvencia y la elocuencia.

\section{Referencias bibliográficas}

Miłosz, C. (1984). Tierra inalcanzable. Trad. de Xavier Farré. Galaxia Gutenberg / Círculo de Lectores.

Mistral, G. (2016). Caperucita roja. Amanuta. 